\title{
EFFECT OF PLANT EXTRACTS ON SPORULATION AND SPORE GERMINATION OF STORED MELON SEED FUNGI
}

Amadi J.E. ${ }^{* 1}$, Adeleke E.E. ${ }^{2}$, Olahan G. ${ }^{3}$, Garuba T. ${ }^{4}$ and Adebola M.O. ${ }^{5}$

${ }^{* 1}$ Department of Botany, Nnamdi Azikiwe University, PMB 5025, Awka, Nigeria

${ }^{2,3,4}$ Department of Plant Biology, Univ. Ilorin, Nigeria

${ }^{5}$ Department of Biological Sciences, Ibrahim Badamasi Babangida University, Lapai, Niger State *Correspondence Author: jamadi2009@yahoo.com

\begin{abstract}
:
Frequently, stored melon seeds fail to preserve to their time of use. Storage fungi invade these seeds and cause their deterioration. A study was, therefore, carried out to determine the effect of guava (Psidium guajava L.) leaf and ginger (Zingiber officinale) rhizome extracts on the sporulation and spore germination of the invading seed fungi. Dried leaves and rhizomes were ground in sterile mortar, filtered through a wire sieve and then extracted using three different solvents. Results revealed that both extracts hindered sporulation and spore germination in the four fungi tested namely: Aspergillus flavus, A. niger, Rhizopus stolonifer and Fusarium species. The effect of the extracts on the test organisms increased with concentration of the extracts. Phytochemical screening confirmed the presence of alkaloids, saponins, lipids, tannins, flavonoids, and steroids. A reduction in nutrient contents was also observed in infested melon seeds. These results are significant and would serve as a template for planning the control of storage fungi in melon seeds in particular and other crop produce in general.
\end{abstract}

Keywords:

Concentration, extract, fungi, melon, solvent, storage.

\section{INTRODUCTION}

Melon (Citrullus colocynthis) is a creeping annual plant, which thrives well on rich light soil in the hot climate regions of Africa. In the south-eastern region of Nigeria, it is best cultivated after the first rain of each year and harvested about thirteen weeks after planting [2]. The plant has large, fleshy, perennial roots, with slender, tough, angular, vine-like stems. The leaves are angular and lobed with yellow, solitary flowers in the axils of the leaves. The fruit is globular, smooth with a hard but thin rind like a gourd. The fruit is filled with a soft white pulp in which are embedded numerous seeds. These seeds are washed and dried properly before storage. Citrullus colocynthis is a widely cultivated and consumed oil seed crop in West Africa [9]. Melon seeds, popularly called "egusi" in the eastern and south-eastern parts of Nigeria, are edible and rich in fat, protein, vitamins and minerals [20;25]. During storage, melon seeds are attacked by several different fungi which both reduce the food nutrients as well as the market value of infected seeds. One major challenge melon seeds face in storage is that of deterioration and several fungi have been implicated. Fungi of the genera Aspergillus and Penicillium are widely distributed storage fungi of melon seeds, causing seed discoloration, decrease in nutritional value, increase in free fatty acid and peroxide values, decreased seed germination and production of a number of toxic metabolites, including aflatoxin [10; 9]. Adeleke et al., (2012) have reported Aspergillus flavus, A. niger, Rhizopus stolonifer, Burgoa nigra and Fusarium sp. in stored melon seeds. Seed deterioration constitutes a major constraint to all year round availability of melon in Nigeria and other parts of the world.

There is the need for efficient and economic means of controlling the activities of melon seed fungi. The constraints surrounding the use of chemical fungicides gave rise to the exploitation of botanicals, otherwise known as plant extracts, as a safer, cheaper and effective plant disease control measure [4]. According to Babu et al. (2008) and Yasmin et al. (2008), the use of plant extracts in the control of plant diseases is gaining importance because of the growing awareness on the hazardous effects of chemical fungicides to human health and environment. Plant extract is a collection of crude mixtures extracted from different parts of plants. Present advances in screening and separation technologies revealed extract bioactivity with great efficiency and accuracy. A current technique involving Direct Screening of Natural Products' Extracts using Mass Spectrometry does not require any preparation or fractionation work. With this method, several hundred crude extracts can be screened in a day. 


\section{INTERNATIONAL JOURNAL Of RESEARCH - GRANTHAALAYAH \\ A knowledge Repository}

The aim of this study is to determine the effect of fresh guava (Psidium guajava L.) leaf and ginger (Zingiber officinale) rhizome extracts on the sporulation and spore germination of fungi associated with stored melon seeds with a view to controlling deterioration of melon seeds in storage.

\section{MATERIALS AND METHODS}

\subsection{PREPARATION OF PLANT EXTRACTS}

Healthy fresh guava leaves were washed under running tap, rinsed with sterile distilled water and air-dried under shade in the laboratory for 7 days. The ginger rhizomes were similarly washed, chopped into small pieces, wrapped in aluminum foil and then dried in an oven at $85^{\circ} \mathrm{C}$ for 24 hours. The dried leaves and rhizomes were ground separately using sterile mortar and pestle and filtered through a sterile wire sieve. Three different solvents were used for the extraction process, water, ethanol and acetone. Ten grams $(10 \mathrm{~g})$ of the fine powder of either material were dissolved in $100 \mathrm{ml}$ of each of the solvents [17] to obtain the stock solution of the extract. The stock solutions were left for $24 \mathrm{hr}$ on laboratory bench and later filtered aseptically into conical flasks. The extracts were stored in a refrigerator and used as required.

\subsection{EFFECT OF PLANT EXTRACTS ON SPORULATION AND SPORE GERMINATION}

Potato dextrose broth was used for this study. The broth was amended with three concentrations of the extracts $(5 \%, 15 \%$ and $25 \%)$, dispensed aseptically into sterile conical flasks and inoculated with $4 \mathrm{~mm}$ mycelial discs of each isolate. The flasks were incubated at room temperature for $24 \mathrm{hr}$ and then filtered through filter paper. The filtrate of each culture was checked for spore production using an improved Neubauer haemocytometer [15]. Spore concentration was recorded for each extract concentration.

For spore germination, spore suspensions were prepared as described above using potato dextrose broth amended with different concentrations of the plant extracts. Using a sterile pipette, two drops of the suspension were placed in a clean glass slide and placed on a U-tube inside the micro-humidity chamber. The slides were examined at intervals under the microscope for conidia germination. The percentage of spore germination was calculated thus:

Percentage germination $=\quad \underline{\text { No. of germinated spore }} \times 100$

Total number of spores

\subsection{PHYTOCHEMICAL SCREENING OF PLANT EXTRACTS}

The plant extracts were screened for the phytochemical contents at Department of Chemistry, University of Ilorin, Kwara State. Three solvents, water, ethanol and acetone were used. The phytochemicals screened for were carbohydrates, lipids, steroids, alkaloids, phenolics, anthraquinones, flavonoids, tannins and saponins. Routine procedures were employed for these tests $[11 ; 19 ; 24 ; 23]$.

\subsection{PROXIMATE ANALYSIS OF MELON SEEDS}

Proximate analysis of melon seeds was carried out based on the separation of food components into groups or fractions in accordance with their nutritional value. The components tested were water/moisture, crude protein, oil, crude fibre, and mineral matter or ash. Routine procedures 


\section{INTERNATIONAL JOURNAL Of RESEARCH - GRANTHAALAYAH

were also used for this analysis [6]. Statistical analysis was carried out for all the results as appropriate.

\section{RESULTS AND DISCUSSIONS}

\subsection{SPORULATION AND SPORE GERMINATION}

The effects of plant extracts on sporulation and spore germination of four fungal isolates were determined. The isolates were A. flavus, A. niger, R. stolonifer and Fusarium species. The fifth isolate identified in this study as B. nigra did not produce any spores and rather formed entangled masses of hyphae known as chlamydospores. All the isolates sporulated heavily in the potato dextrose broth used for this study. However, when the medium was amended with different concentrations of the extracts, it was observed that fewer spores were produced at all the concentrations tested. Reduction in sporulation increased with increasing concentration of the extracts. It was also observed in this study that luxuriant mycelial growth corresponded with less sporulation and vice versa.

Inhibition of sporulation of A. flavus was observed with ethanolic ginger extract at $25 \%$ concentration (Table 1). Acetone ginger extract and ethanolic guava extract at $25 \%$ concentration reduced sporulation of $A$. niger. Aqueous ginger extract also had an inhibitory effect on sporulation of $R$. stolonifer. All the test plant extracts had inhibitory effects on sporulation of Fusarium sp., compared with the control. At 5\% concentration of acetone guava extract, Fusarium sp. produced $4.60 \times 10^{5}$ spores while at $25 \%$ aqueous ginger extract, the number of spores produced was $1.1 \times 10^{5}$ spore counts (Table 2).

Table 1: Effect of plant extracts on sporulation of Aspergillus flavus

\begin{tabular}{|c|c|c|c|c|c|c|c|}
\hline & $\begin{array}{l}\text { Aqueous } \\
\text { ginger } \\
\text { extract }\end{array}$ & $\begin{array}{l}\text { Ethanolic } \\
\text { ginger } \\
\text { extract }\end{array}$ & $\begin{array}{l}\text { Acetone } \\
\text { ginger } \\
\text { extract }\end{array}$ & $\begin{array}{l}\text { Aqueous } \\
\text { guava } \\
\text { extract }\end{array}$ & $\begin{array}{l}\text { Ethanolic } \\
\text { guava } \\
\text { extract }\end{array}$ & $\begin{array}{l}\text { Acetone } \\
\text { guava } \\
\text { extract }\end{array}$ & Control \\
\hline $5 \%$ & $2.30 \times 10^{5}$ & $2.85 \times 10^{5}$ & $4.55 \times 10^{5}$ & $\begin{array}{ll}3.60 & \mathrm{x} \\
10^{5} & \end{array}$ & $2.90 \times 10^{5}$ & $9.60 \times 10^{5}$ & $5.25 \times 10^{5}$ \\
\hline $15 \%$ & $2.45 \times 10^{5}$ & $1.55 \times 10^{5}$ & $3.00 \times 10^{5}$ & $\begin{array}{l}3.30 \quad x \\
10^{5}\end{array}$ & $2.55 \times 10^{5}$ & $1.29 \times 10^{6}$ & \\
\hline $25 \%$ & $3.75 \times 10^{5}$ & $8.50 \times 10^{4}$ & $2.80 \times 10^{5}$ & $\begin{array}{ll}2.90 \quad \mathrm{x} \\
10^{5}\end{array}$ & $2.20 \times 10^{5}$ & $1.37 \times 10^{6}$ & \\
\hline
\end{tabular}

Table 2: Effect of plant extracts on sporulation of Fusarium sp.

\begin{tabular}{|l||l|l|l|l|l|l|l|}
\hline & $\begin{array}{l}\text { Aqueous } \\
\text { ginger } \\
\text { extract }\end{array}$ & $\begin{array}{l}\text { Ethanolic } \\
\text { ginger } \\
\text { extract }\end{array}$ & $\begin{array}{l}\text { Acetone } \\
\text { ginger } \\
\text { extract }\end{array}$ & $\begin{array}{l}\text { Aqueous } \\
\text { guava } \\
\text { extract }\end{array}$ & $\begin{array}{l}\text { Ethanolic } \\
\text { guava } \\
\text { extract }\end{array}$ & $\begin{array}{l}\text { Acetone } \\
\text { guava } \\
\text { extract }\end{array}$ & Control \\
\hline \hline $5 \%$ & $2.30 \times 10^{5}$ & $3.40 \times 10^{5}$ & $3.30 \times 10^{5}$ & $\begin{array}{l}2.30 \times \\
10^{5}\end{array}$ & $2.70 \times 10^{5}$ & $4.60 \times 10^{5}$ & $5.65 \times 10^{5}$ \\
\hline $15 \%$ & $1.60 \times 10^{5}$ & $2.30 \times 10^{5}$ & $2.10 \times 10^{5}$ & $\begin{array}{l}1.60 \quad \times \\
10^{5}\end{array}$ & $2.10 \times 10^{5}$ & $1.40 \times 10^{5}$ & \\
\hline & & & & $1.40 \times \mathrm{x}$ \\
$15 \%$ & $1.10 \times 10^{5}$ & $1.60 \times 10^{5}$ & $1.55 \times 10^{5}$ & $10^{5}$ & $1.20 \times 10^{5}$ & $1.20 \times 10^{5}$ & \\
\hline
\end{tabular}




\section{INTERNATIONAL JOURNAL Of RESEARCH - GRANTHAALAYAH \\ A knowledge Repository}

Results of this study showed that the effect of plant extracts on spore germination of the test organisms was very similar to the observed effects on sporulation (Figures 1-3). The effects ranged from minor inhibition to complete inhibition of germination. Complete inhibition of germination of $A$. niger spores was observed at $25 \%$ concentration of ethanolic ginger extract, acetone ginger extract and ethanolic guava extract. All the plant extracts used in this study inhibited germination of $A$. niger spores with inhibition increasing with concentration of the extracts. Spore germination in $R$. stolonifer was inhibited effectively by ethanolic ginger and guava extracts at 15 and $25 \%$ concentration while other extracts showed different levels of inhibition. Statistical analysis showed that the effects of extracts on sporulation and spore germination were significantly different at $5 \%$.

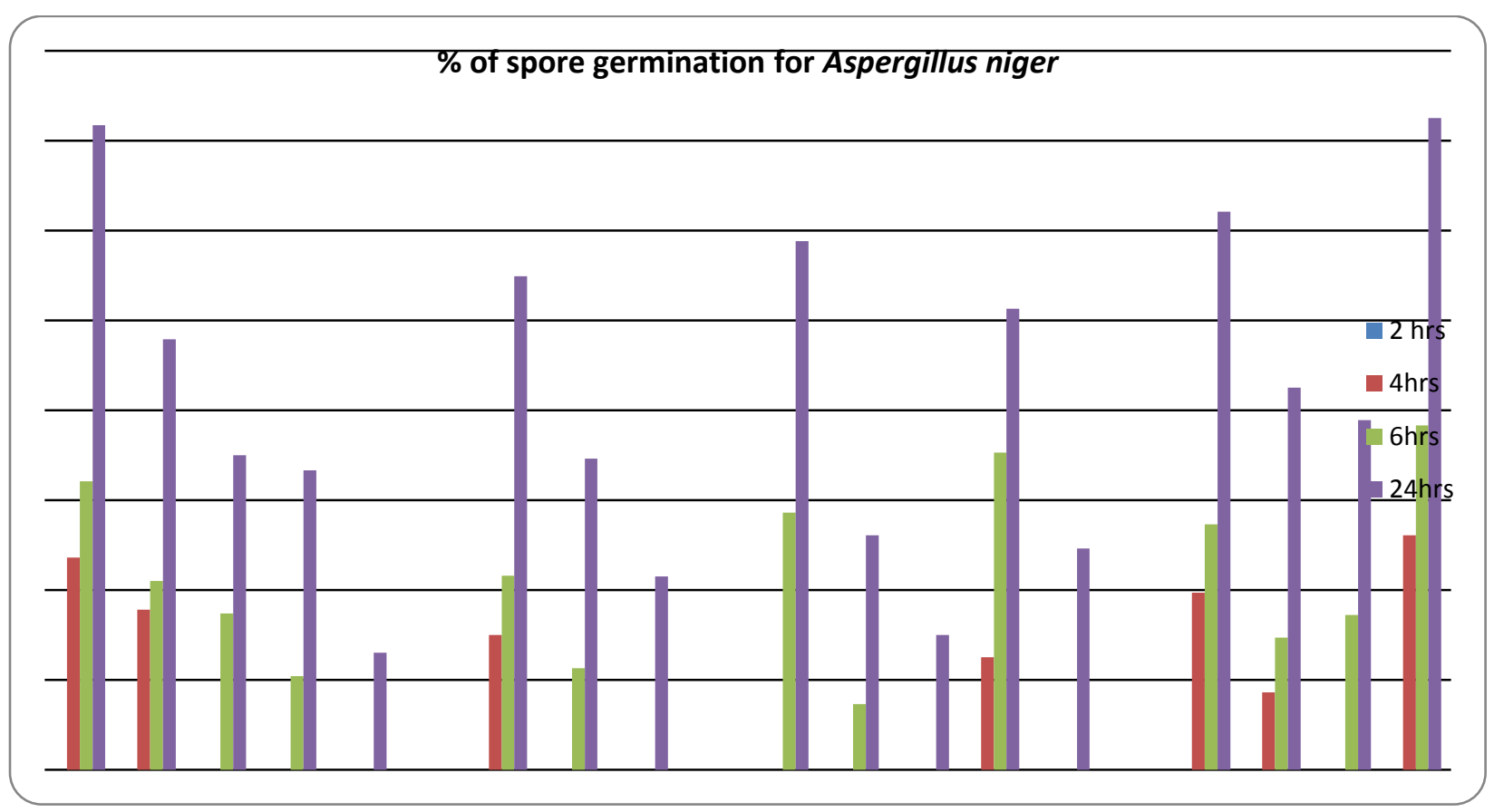

Figure 1: Effect of ginger and guava extracts on spore germination of Aspergillus niger at different concentrations.

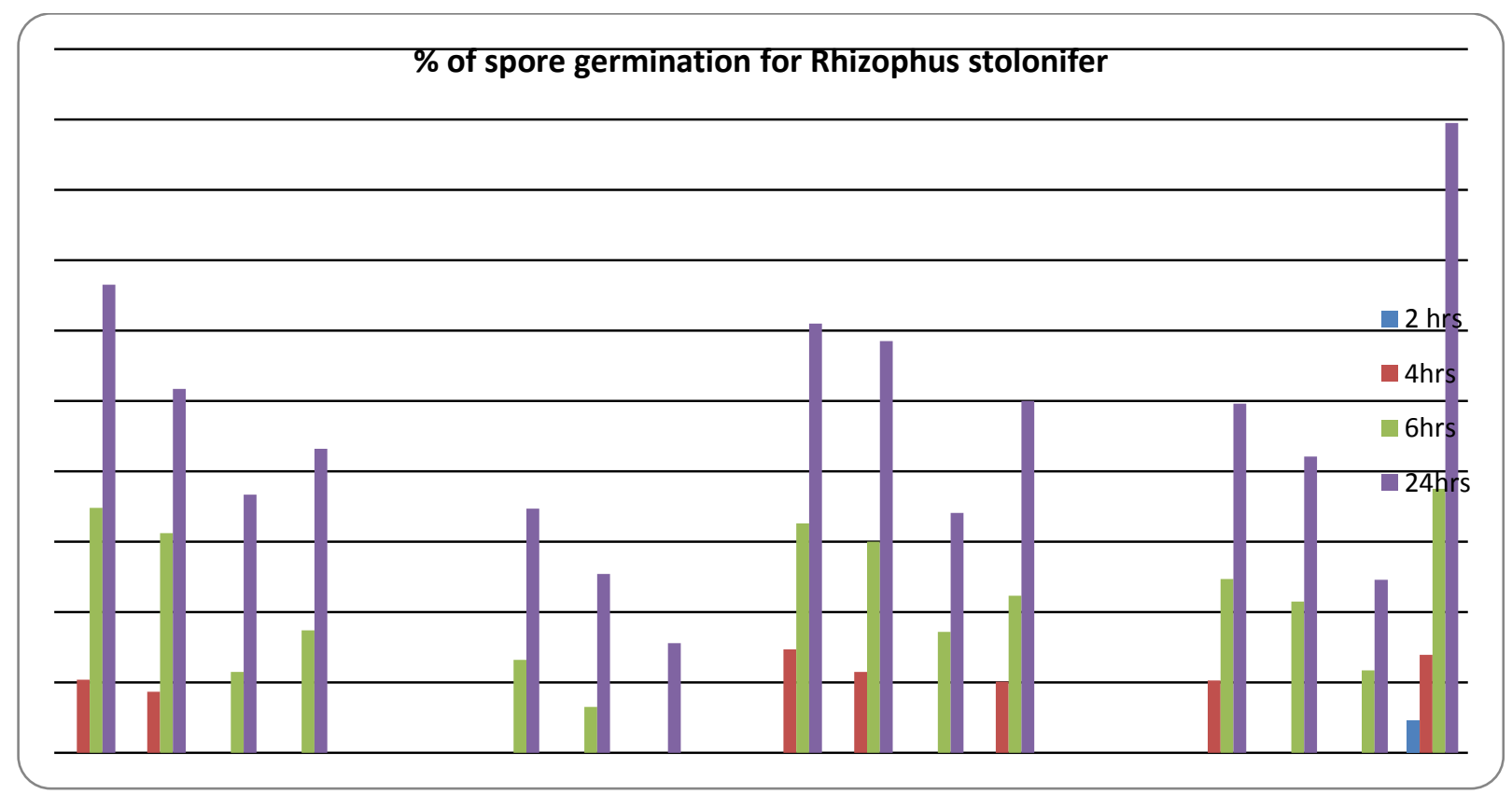

Figure 2: Effect of ginger and guava extracts on spore germination of Rhizophus stolonifer at different concentrations. 


\section{INTERNATIONAL JOURNAL Of RESEARCH - GRANTHAALAYAH

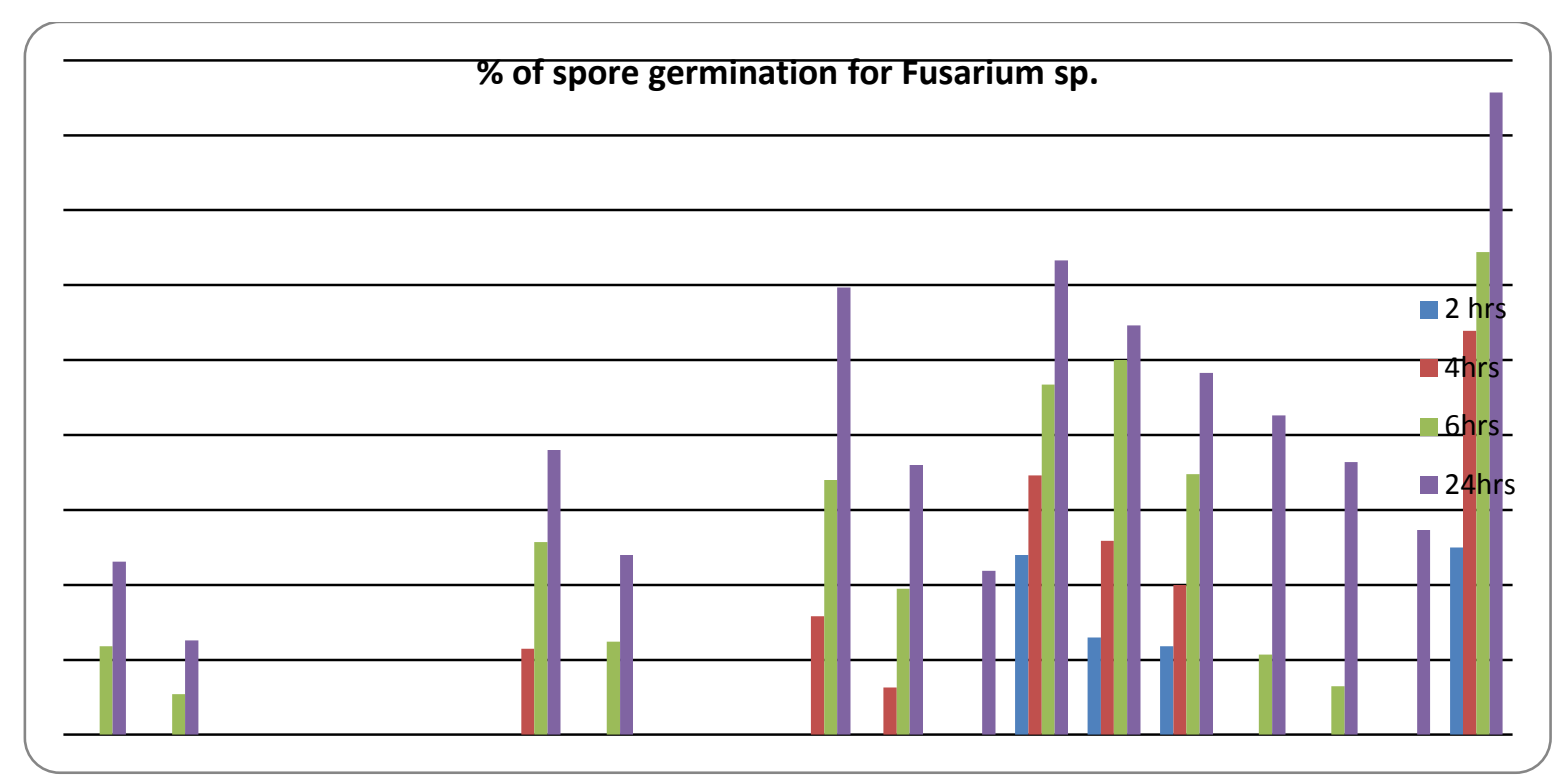

Figure 3: Effect of ginger and guava extracts on spore germination of Fusarium sp. at different concentrations.

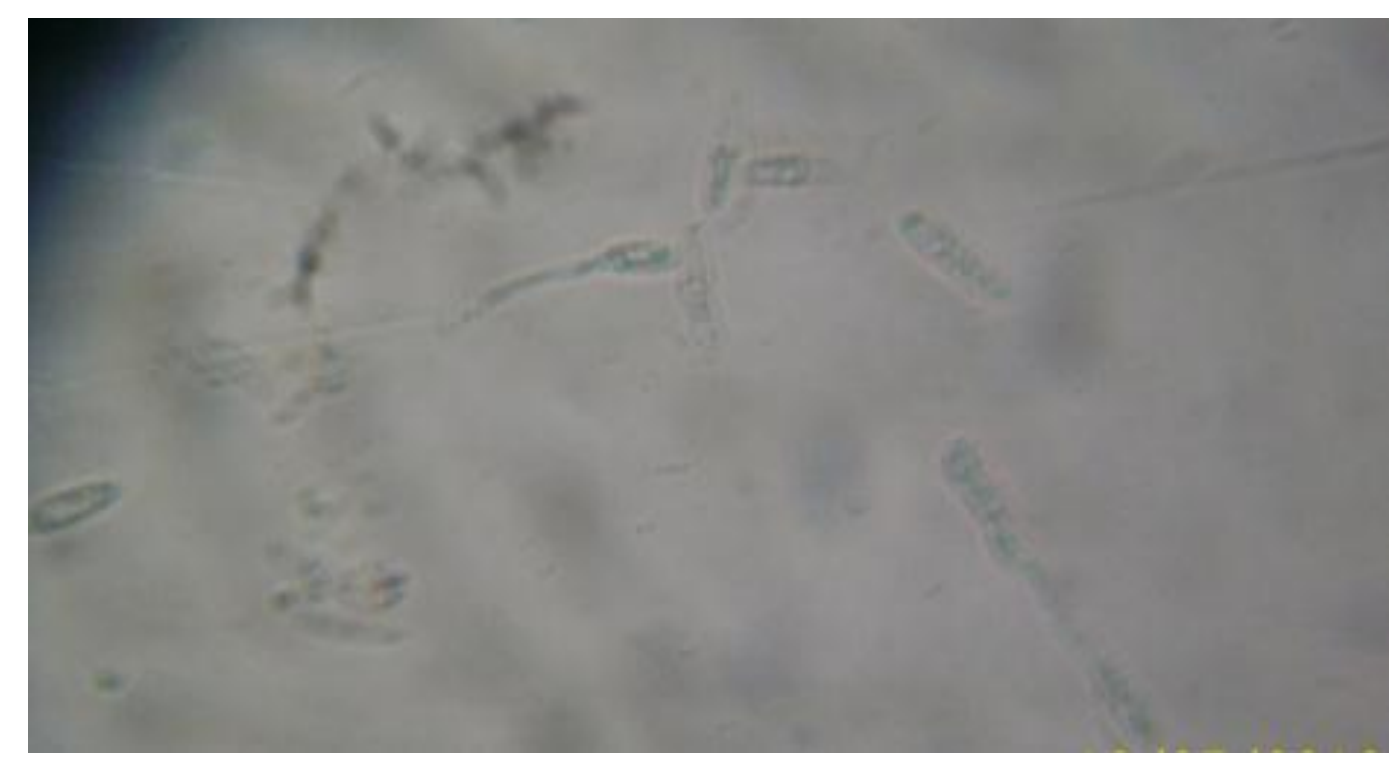

Plate 1: Germinating spores of Fusarium sp.

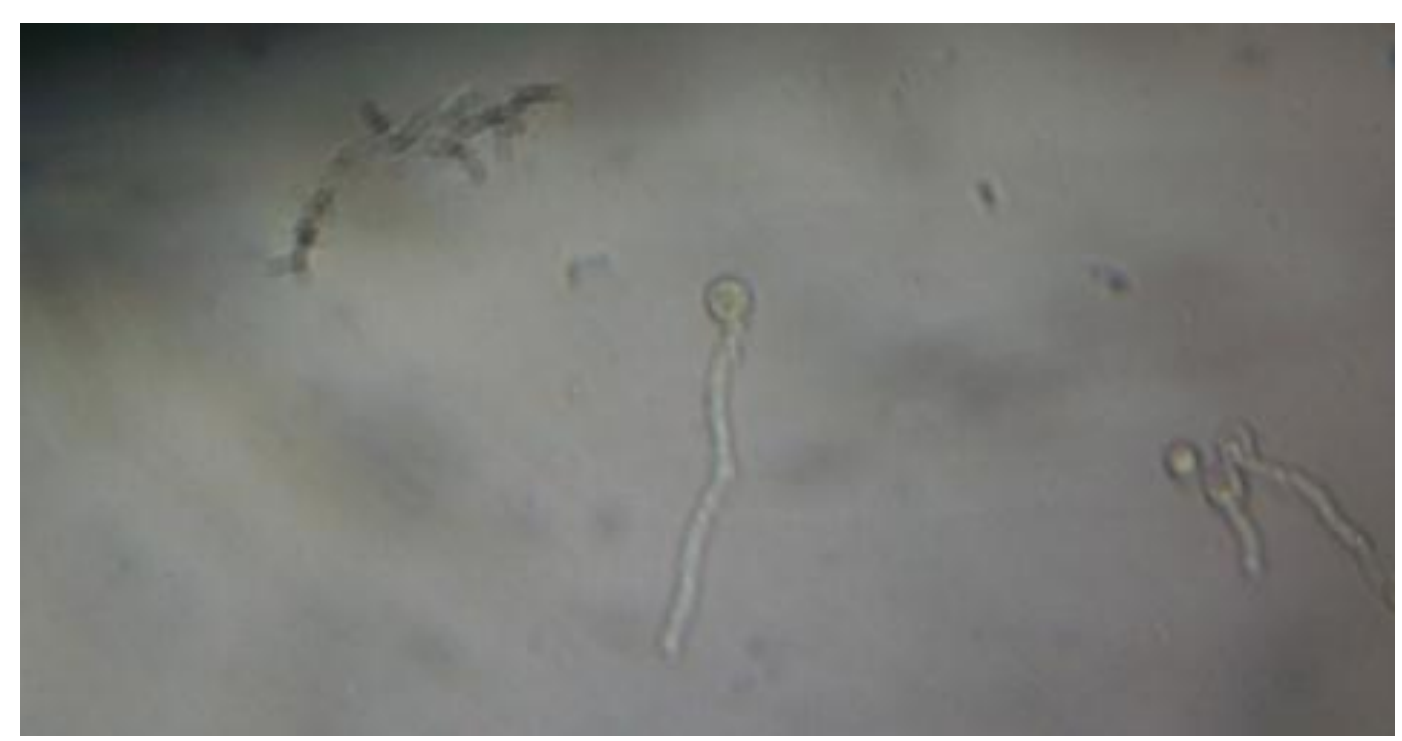

Plate 2: Germinating spores of Aspergillus sp. 


\section{INTERNATIONAL JOURNAL Of RESEARCH - GRANTHAALAYAH \\ A knowledge Repository}

\subsection{PHYTOCHEMICAL SCREENING OF PLANT EXTRACTS}

Phytochemical screening results show that reducing sugar (carbohydrate), tannins, flavonoids, and steroids are present in all the plant extracts assayed (Table 3). Ethanolic and acetone extracts of guava leaves showed the presence of lipids. Saponins were present in aqueous ginger extract and also in aqueous and acetone guava leaf extracts. Anthraquinones were detected in ethanolic, acetone, and aqueous ginger extracts. Alkaloids were present in aqueous and acetone extracts of ginger and guava.

Table 3: Secondary Metabolites detected in the Different Plant Extracts Screened

\begin{tabular}{|c|c|c|c|c|c|c|c|}
\hline Secondary metabolite & Treatments & $\begin{array}{l}\text { Aqueous } \\
\text { ginger }\end{array}$ & $\begin{array}{l}\text { Ethanolic } \\
\text { ginger }\end{array}$ & $\begin{array}{l}\text { Acetone } \\
\text { ginger }\end{array}$ & $\begin{array}{l}\text { Aqueous } \\
\text { guava }\end{array}$ & $\begin{array}{l}\text { Ethanolic } \\
\text { guava }\end{array}$ & $\begin{array}{l}\text { Acetone } \\
\text { guava }\end{array}$ \\
\hline \multirow[t]{2}{*}{ 1. Carbohydrate } & Barfoed test & + & + & + & + & + & + \\
\hline & Fehling's test & + & + & + & + & + & + \\
\hline 2. Lipid test & $\begin{array}{l}\text { Liebermann storch } \\
\text { test }\end{array}$ & - & - & - & - & + & + \\
\hline 3. Tannins & Ferrichloride test & + & + & + & + & + & + \\
\hline \multirow[t]{4}{*}{ 4. Flavonoids } & $\begin{array}{l}\text { Sodium hydroxide } \\
\text { test }\end{array}$ & + & + & + & + & + & + \\
\hline & Minerial acid test & - & + & + & + & - & - \\
\hline & Ferrichloride test & + & + & + & + & + & + \\
\hline & Lead acetate & - & + & + & + & + & + \\
\hline 5. $\quad$ Steroids & Saltowski test & + & + & + & + & + & + \\
\hline 6. $\quad$ Saponins & Frothing test & + & - & - & + & - & + \\
\hline 7. Anthraquinones & Borntrager's test & - & + & + & + & - & - \\
\hline 8. Alkaloids & Mayer's reagent test & + & - & + & + & - & + \\
\hline
\end{tabular}

\subsection{PROXIMATE ANALYSIS OF MELON SEEDS}

Results of proximate analysis show that nutritional contents of deteriorated melon seeds reduced when compared with those of healthy seeds. The moisture and carbohydrate contents were, however, found to be higher in infested than in healthy seeds (Table 4). There was no significant difference at $5 \%$ between the nutrients in healthy and deteriorated melon seeds.

Table 4: Nutrient Contents of Healthy and Deteriorated Melon Seeds.

\begin{tabular}{|l|l|l|}
\hline Nutrient & Healthy seeds & Infested seeds \\
\hline Moisture content & $5.39 \pm 0.03$ & $5.90 \pm 0.01$ \\
\hline Total ash & $4.21 \pm 0.12$ & $3.99 \pm 0.01$ \\
\hline Crude fibre & $1.36 \pm 0.01$ & $1.30 \pm 0.02$ \\
\hline Fat content & $44.35 \pm 0.01$ & $41.98 \pm 0.04$ \\
\hline Crude protein & $34.91 \pm 0.15$ & $31.33 \pm 0.08$ \\
\hline Carbohydrate & $9.78 \pm 0.04$ & $15.50 \pm 0.03$ \\
\hline
\end{tabular}

\subsection{DISCUSSION}




\section{INTERNATIONAL JOURNAL Of RESEARCH - GRANTHAALAYAH

The importance of food to man is cannot be over emphasized. Therefore, it is worth all the effort to preserve food stuffs from deterioration to ensure their availability in and out of season. Deterioration of food stuffs is caused by an array of micro-organisms. Melon seed is an important oil seed that is consumed and enjoyed by most Nigerians and is subject to such infestation by fungi. The quality of melon seed is an important parameter for marketing and processing. Quality characters of seed such as germinability, moisture content, discoloration and seed infestation are known to be influenced by various factors during storage [18]. Various researchers have implicated different fungi in the deterioration of melon seeds in storage $[9 ; 1]$.

The extensive use of agrochemicals especially fungicides in the control of seed-borne fungi, has been roundly criticized for the health risks associated with their use [21]. Thus, the use of plant extracts of many species of plants has been reported to be effective against many fungi. Many higher plants are known to produce economically important organic compounds, pharmaceuticals and pesticides. In the present study, guava and ginger plant extracts were effective in inhibiting sporulation and spore germination of A. flavus, A. niger, R. stolonifer and Fusarium species at different concentrations. Silva et al. (2000) had reported fungicidal and fungistatic effect on Alternaria spp., Fusarium spp., Pestalotiopsis spp. and Rhizopus species using extracts of twenty different plants including guava (Psidium guajava L.). Alkhail (2005) showed that aqueous extracts of plants viz., Allium sativum, Cymbopogon proxims, Carum carvi, Azadirachta indica and Eugenia caryophyllus had strong antifungal activity against Fusarium oxysporum, Botrytis cinerea and Rhizoctonia solani. Zingiber officinale extract had been reported to have inhibitory effect on $F$. oxysporum [5].

Result of the phytochemical screening of ginger and guava extracts in this study showed the presence of some secondary metabolites namely: tannins, alkaloids, flavonoids, anthraquinones, saponins and steroids. Presence of these secondary metabolites is suggestive of the presence of antifungal property in these extracts. Hamburger and Hostettmann (1991) had reported that the total number of plant chemicals may exceed 400,000 out of which more than 10,000 are secondary metabolites whose major role in plant is defensive in nature. Thus, plant based secondary metabolites, which have defensive role may be exploited for the management of storage microbes.

Nutritional components of melon seeds were reduced in infested melon seeds when compared with healthy seeds in this study. Ekundayo and Idzi (1990) had reported a decrease in the crude protein, crude fibre and total carbohydrate contents in seeds inoculated with fungal isolates for 14 days. Fungi consume the oil in invaded seeds. The decreased oil content observed in deteriorated melon seeds compared to healthy seeds is in line with the observation of Bankole and Joda (2004). Chakrabarti (1987) had reported A. flavus and A. tamari to be highly lipolytic. Storage of seeds with their high moisture content promote mould invasion and affects the germinability of the seeds [13]. The moisture content plays a vital role in the maintenance of seed quality in stores. To reduce loss of quality in stored products, rapid drying to low moisture is often emphasized, because most occurrences of mould contamination and subsequent damage occur when products are not stored at safe moisture contents [9].

\section{CONCLUSIONS \& RECOMMENDATIONS}

In conclusion, it has been shown that the extracts tested in this study have the potency to check the deterioration of stored melon seeds. Phytochemical screening confirmed the presence of alkaloids, saponins, lipids, tannins, flavonoids, and steroids. A reduction in nutrient contents was also observed in infested melon seeds. These results are significant because it implies that the test extracts can be incorporated into a template to achieve the control of storage fungi in general and the test organisms of this study in particular. However, there may be a limitation to the application of this result arising from the fact that the outcome of field tests does not always follow the laboratory trend. The findings of this study are in tandem with earlier reports on plant extracts.

\section{REFERENCES}

[1] Adeleke, E. E., Amadi, J.E., and Adebola, M.O. Studies on the Fungi Involved in the Deterioration of Stored Melon Seeds (Citrullus colocynthis (L.) Schrad in Ilorin Metrpolis 


\section{INTERNATIONAL JOURNAL Of RESEARCH - GRANTHAALAYAH

and Control. Journal of Applied Sciences, 15(2): 2012, 10590-10602.

[2] Akpambang, V. O. E., Amoo, I. A. and Izuagie, A. A. Comparative Compositional Analysis on Two Varieties of Melon (Colocynthis citrullus and Cucumeropsis edulis) and a Variety of Almond (Prunus amygdalus), Research Journal of Agriculture and Biol. Sciences, 4(6), 2008, 639-642.

[3] Alkhail, A.A. Antifungal Activity of Some Extracts against Some Plant Pathogenic Fungi, Pak. J. Biol. Sci., 8(3), 2005, 413-417.

[4] Amadi, J.E. Importance and Efficacy of Plant Extracts in Plant Disease Control:

A Review. Journal of Applied Sciences, 14(3), 2011, 10093-10102.

[5] Amienyo, C. A. and Ataga, A. E. Use of Indigenous Plant Extracts for the Protection of Mechanically Injured Sweet Potato (Ipomoea batatas (L.) Lam.) Tubers, Scientific Research and Essay, 2(5), 2007, 167-170.

[6] AOAC. Official Methods of Analysis, 15th edition. Association of Official Analytical Chemists, Arlington, VA. 1990.

[7] Babu, J., Muzafar, A. D. and Vinod, K. Bioefficacy of Plant Extracts to Control Fusarium solani F. Sp. Melongenae Incitant of Brinjal Wilt, Global Journal of Biotechnology and Biochemistry, 3(2), 2008, 56-59.

[8] Bankole, S. A. and Joda, A. O. Effect of Lemon Grass (Cymbopogon citratus Strapf) Powder and Essential Oil on Mould Deterioration and Aflatoxin Contamination of Melon Seed (Colocynthis citrullus L.), African Journal of Biotechnology, 3(1), 2004, 52-59.

[9] Bankole, S. A., Osho, A., Joda, A. O. and Enikuomehin, O. A. Effect of Drying Method on the Quality and Storability of "egusi" Melon Seed (Colocynthis citrullus L.), African Journal of Biotechnology, 4(8) 2005, 799-803.

[10] Basra, S. M. A., Khalil-Ur-Rehman and Sajjad, I. Cotton Seed Deterioration: Assessment of Some Physiological and Biochemical Aspects, International Journal of Agriculture and Biology, 2(3), 2001, 195-198.

[11] Brain, K. R. and Turner, T. D. The Practical Evaluation of Phytopharmaceuticals.

Wright-Scientica, Bristol. Pp. 1975, 57-58.

[12] Chakrabarti, D. K. A Review of Deterioration of Oil Seeds with Special Reference to India, Int. Biodeter, 23, 1987, 137-157.

[13] Chiejina, N. V. Studies on Seed-borne Pathogens of Some Nigerian Melons, Journal of Agriculture, Food, Environment and Extension, 5(1), 2006, 13-16.

[14] Ekundayo, C. A. and Idzi, E. Mycoflora and Nutritional Value of Shelled Melon Seeds (Citrulus vulgaris Schrad.) in Nigeria, Plant Foods for Human Nutrition (formally Qualitas Plantarum), 40(3), 1990, 215-222.

[15] Fawole, M. O. and Oso, B. A. Laboratory Manual of Microbiology, Spectrum books limited, Ibadan. Pp. 2004, 46-55.

[16]Hamburger, $M$. and Hostettmann, $K$. Bioactivity in Plants: The Link Between Phytochemistry and Medicine, Phytochemistry, 30, 1991, 3864-3874.

[17] Malabadi, R. B. and Kumar, S. V. Assessment of Antifungal Activity of Some Medicinal Plants, International Journal of Pharmacology, 3, 2007, 499-504.

[18] Malaker, P. K., Mian, I. H., Bhuiyan, K. A., Akanda, A. M. and Reza, M. M. A. Effect of Storage Containers and Time on Seed Quality of Wheat, Bangladesh J. Agril. Res., 33(3), 2008, 469-477.

[19] Odebiyi, A. and Sofowora, A. E. Phytochemical Screening of Nigeria Medicinal Plants (part III), Lloydia, 41, 1978, 73-78.

[20] Olaniyi, J. O. Growth and Seed Yield Response of Egusi Melon to Nitrogen and Phosphorus Fertilizers Application, American-Eurasian Journal of Sustainable Agric., 2(3), 2008, 255-260.

[21] Osman, K. A. and Abdulrahman, H. T. Risk Assessment of Pesticide to Human and the Environment, Saudi J. Biol. Sci., 10, 2003, 81-106. 


\section{INTERNATIONAL JOURNAL Of RESEARCH - GRANTHAALAYAH

[22] Silva, B. B., Monica, H. L. and Laura, L. B. Antifungal Screening of Plants of the State of Morelos, Mexico Against Four Fungal Postharvest Pathogens of Fruits and Vegetables, Revista Mexicona de Fitopatologia, 18(1), 2000, 36-41.

[23] Sofowora, A. Medicinal Plants and Traditional Medicine in Africa. Spectrum Books Limited, Ibadan, Nigeria. Pp. 1993, 151-153.

[24] Trease, G.E., and Evans, W.C. Pharmacognosy. $13^{\text {th }}$ edition. Bailliere Tindall, London. Pp. 1989, 176-180.

[25] Wikipedia. Colocynth. http://en.wikipedia.org/wiki/Colocynth, 2010.

[26] Yasmin, M., Hossain, K. S. and Bashar M. A. Effects of Some Angiospermic Plant Extracts on in vitro Vegetative Growth of Fusarium moniliforme, Bangladesh Jour. Botany, 37(1), 2008, 85-88. 